\title{
PERLINDUNGAN HUKUM TERHADAP PEKERJA BERSTATUS PERJANJIAN KERJA WAKTU TERTENTU (PKWT) MENURUT UNDANG-UNDANG NOMOR 13 TAHUN 2003 TENTANG KETENAGAKERJAAN
}

\author{
Asuan \\ Fakultas Hukum Universitas Palembang \\ asuan.okay@gmail.com
}

\begin{abstract}
This study is a normative juridical approach with an approach to problems that see in terms of applicable laws and regulations, especially regarding labor law / labor. This study uses secondary data with the preparation of a conceptual framework, to obtain legal materials in the form of theories, concepts and legal principles obtained from the literature, among others, books, documents, articles, and other literature. Legislation, namely Law No. 13 of 2003 concerning Labor, the Civil Code and other legal regulations relating to problems. The results of the discussion, namely the protection of workers with an inter-time employment agreement (PKWT) according to Law Number 13 of 2003 concerning Employment, namely: Protection of work hours namely 7 (seven) hours in 1 (one) day and 40 hours 1 (one) week for 6 (six) working days in 1 (one) week; or 8 (eight) hours in 1 (one) day and 40 hours 1 (one) week for 5 (five) working days in 1 (one) week. (Article 77 paragraph 1); Protection against wages, namely provincial minimum wages and district / city minimum wages (Article 88 paragraph (3) letter a); protection of welfare, that is workers / laborers and their families have the right to obtain social security workers. and includes family planning services, child care, workers' housing, worship facilities, sports facilities, canteen, health, recreation and the establishment of cooperative facilities, of course the provision of these facilities is carried out with the company's ability (Article 99 paragraph 1 and 100 verses 1 and 2), and Protection of Social Security, namely the Social Security Program includes collateral for death, work accident insurance, old age guarantee and health care guarantee (article 99). The constraints in legal protection of workers in certain time work agreements (PKWT) are related to regulations, relating to work agreements and related to supervision.
\end{abstract}

Keywords: Worker; protection; Work agreement

\begin{abstract}
ABSTRAK
Penelitian ini adalah penelitian yuridis normatif dengan pendekatan terhadap masalah yang melihat dari segi peraturan perundangan yang berlaku khususnya tentang hukum ketenagakerjaan/perburuhan. Penelitian ini menggunakan data sekunder dengan penyusunan kerangka secara konsepsionil, untuk mendapatkan bahan-bahan hukum berupa teori-teori, konsepkonsep dan asas-asas hukum yang diperoleh dari kepustakaan antara lain buku, dokumen, artikel, serta literatur lainnya. Peraturan perundang-undangan yaitu Undang-Undang No. 13 Tahun 2003 tentang Ketenagakerjaan, KUH Perdata dan peraturan hukum lainnya berhubungan dengan permasalahan. Hasil pembahasan yakni perlindungan pekerja dengan perjanjian kerja antar waktu (PKWT) menurut Undang-Undang Nomor 13 Tahun 2003 tentang Ketenagakerjaan yaitu: Perlindungan terhadap waktu kerja yaitu 7 (tujuh) jam dalam 1 (satu) hari dan 40 jam 1 (satu) minggu untuk 6 (enam) hari kerja dalam 1 (satu) minggu; atau 8 (delapan) jam dalam 1 (satu) hari dan 40 jam 1 (satu) minggu untuk 5 (lima) hari kerja dalam 1 (satu) minggu. (Pasal 77 ayat1); Perlindungan terhadap pengupahan yaitu upah minimum propinsi dan upah minimum kabupaten/kota (Pasal 88 ayat (3) huruf a); perlindungan terhadap kesejahteraan yaitu pekerja/buruh dan keluarganya berhak untuk memperoleh jaminan sosial tenaga kerja. dan
\end{abstract}


Asuan, Perlindungan Hukum Terhadap Pekerja Berstatus Perjanjian Kerja Waktu Tertentu (PKWT)

Menurut Undang-Undang Nomor 13 Tahun 2003 Tentang Ketenagakerjaan, Halaman 23-31

meliputi pelayanan keluarga berencana, tempat penitipan anak, perumahan pekerja/buruh, fasilitas beribadah, fasilitas olahraga, kantin, kesehatan, rekreasi dan dibentuknya fasiltas koperasi tentunya penyediaan fasilitas tersebut dilaksanakan dengan kemampuan perusahaan (Pasal 99 ayat 1 dan 100 ayat 1 dan 2 ), serta Perlindungan terhadap jamsostek yaitu Program Jamsostek meliputi jaminan Kematian, Jaminan Kecelakaan Kerja, Jaminan Hari Tua dan Jaminan Pemeliharaan Kesehatan (pasal 99). Adapun hambatan-hambatan dalam perlindungan hukum terhadap pekerja dalam perjanjian kerja waktu tertentu (PKWT) yaitu berkaitan dengan peraturan, berkaitan dengan perjanjian kerja dan berkaitan dengan pengawasan

Kata kunci : Perlindunga; pekerja; Perjanjian kerja

\section{PENDAHULUAN}

\section{A. Pendahuluan}

Tenaga kerja merupakan peran yang sangat penting dalam pembangunan nasional. Sumber daya itu berintraksi dengan modal pembangunan yang lain, yaitu sumber daya alam yang ditambah dengan peran teknologi dan pembangunan dimana akan menunjang program pembangunan di bidang ekonomin dan kesejateraan masyarakat. Sehubungan dengan pembangunan nasional tersebut maka dijelaskan dalam UUD 1945 pada pasal 27 ayat (2) berbunyi : Tiap warga negara berhak atas pekerjaan dan penghidupan yang layak bagi kemanusiaan. Secara yuridis dijabarkan lagi dalam UU No. 13 Tahun 2003 tentang Ketenagakerjaan, yang disebutkan dalam 5 UU Ketenagakerjan tentang memberikan perlindungan bahwa "Setiap tenaga kerja memiliki kesempatan yang sama tanpa diskriminasi untuk memperoleh pekerjaan.

Tenaga kerja merupakan penduduk yang berada dalam usia kerja. Menurut Pasal 1 ayat (2) Undang-Undang Nomor 13 Tahun 2003 tentang Ketenagakerjaan (yang selanjutnya disebut Undang-Undang Ketenagakerjaan), Tenaga Kerja adalah setiap orang yang mampu melakukan pekerjaan guna menghasilkan barang dan atau jasa baik untuk memenuhi kebutuhan sendiri maupun untuk masyarakat. Berdasarkan kualitasnya Tenaga Kerja dibagi menjadi 3, yaitu Tenaga Kerja Terdidik adalah tenaga kerja yang memiliki suatu keahlian atau kemahiran dalam bidang tertentu dengan cara pendidikan formal dan non formal, tenaga kerja terlatih adalah tenaga kerja yang memiliki keahlian dalam bidang tertentu dengan pengalaman kerja, tenaga kerja tidak terdidik dan tidak terlatih adalah tenaga kerja kasar yang hanya mengandalkan tenaga saja. ${ }^{1}$

Tenaga kerja adalah objek yaitu setiap orang yang mampu melakukan pekerjaan untuk menghasilkan barang atau jasa untuk kebutuhan sendiri dan orang lain. Pekerja adalah setiap orang yang bekerja untuk orang lain dengan menerima upah berupa uang atau imbalan dalam bentuk lain. Pemberi kerja adalah orang perseorangan atau badan hukum yang mempekerjakan orang lain dengan membayar upah atau imbalan dalam bentuk lain.

Untuk melindungi pekerja dari permasalahan perburuhan yang komplek, Pemerintah mengeluarkan Undang-Undang Ketenagakerjaan, yaitu Undang - Undang Nomor 13 Tahun 2003 tentang Ketenagakerjaan. Mengenai perlindungan bagi pekerja secara umum dalam undang undang tersebut diatur mengenai perlindungan terhadap, penyandang cacat, perlindungan terhadap perempuan, perlindungan terhadap waktu kerja, keselamatan kerja, juga perlindungan dalam hal pengupahan dan dalam hal kesejahteraan.

Perlindungan tersebut sebagian besar hanya berlaku bagi pekerja dengan status tetap atau yang terikat dengan perjanjian kerja waktu tidak tertentu umumnya disebut PKWTT. Sedangkan bagi pekerja dengan perjanjian pekerja waktu tertentu disebut PKWT peraturannya diatur dalam Keputusan Menteri.

Adanya pembagian dengan PKWT dan PKWTT, berawal dari adanya pekerjaan yang memang membutuhkan waktu tertentu

\footnotetext{
${ }^{1}$ www.wikipedia.com, diakses pada hari Senin, 4 September 2018
} 


\section{Asuan, Perlindungan Hukum Terhadap Pekerja Berstatus Perjanjian Kerja Waktu Tertentu (PKWT) \\ Menurut Undang-Undang Nomor 13 Tahun 2003 Tentang Ketenagakerjaan, Halaman 23-31}

(terbatas) dalam pelaksanaan pekerjaannya. Berbeda dengan pekerja dengan PKWTT yang pada pasal 1603p KUHPerdata ayat (1) yang dinyatakan bahwa pekerjaan yang lamanya hubungan kerja tidak ditentukan, baik dalam perjanjian atau peraturan majikan maupun dalam peraturan perundangundangan atau pula menurut kebiasaan. Sedangkan PKWT berdasarkan dalam ayat (1) didasarkan atas jangka waktu tertentu atau selesainya suatu pekerjaan tertentu.

Dari kedua jenis pekerjaan untuk waktu tertentu tesebut diatas (PKWT) atas dasar jangka waktu dan menimbulkan implikasi bagi pekerja. ${ }^{2}$ Implikasi ini disebabkan dengan diakuinya PKWT atas dasar jangka waktu ini menimbulkan interprestasi bahwa pekerjaan yang tidak diadasarkan pada jenis, sifat atau kegiatan yang bersifat sementara dapat diperjanjikan berdasarkan PKWT atas dasar jangka waktu. Penafsiran ini tentu tidak sejalan dengan Pasal 59 ayat (2) Undang-Undang No. 13 Tahun 2003 tentang Ketenagakerjaan, meyebutkan bahwa PKWT tidak dapat diadakan untuk pekerjaan yang bersifat tetap. Menurut dalam ayat (7) dinyatakan bahwa pelanggaran terhadap pasal 59 ayat (2) ini akan berakibat PKWT tersebut batal demi hukum berubah menjadi PKWTT. ${ }^{3}$

$\begin{array}{ccr}\text { Perjanjian } & \text { Kerja Waktu } & \text { Tertentu } \\ \text { (PKWT) yang } & \text { pekerjanya } & \text { sering }\end{array}$
disebut karyawan kontrak adalah perjanjian kerja antara pekerja dengan pengusaha untuk mengadakan hubungan kerja dalam waktu tertentu atau untuk pekerja tertentu. PKWT harus memenuhi syarat-syarat sebagai berikut :

1. Didasarkan atas jangka waktu paling lama tiga tahun atau selesainya suatu pekerjaan tertentu;

2. Dibuat secara tertulis dalam 3 rangkap : untuk buruh, pengusaha dan Disnaker (Permenaker No. Per-02/Men/1993),

\footnotetext{
${ }^{2}$ Aloysius Uwiyono, Implikasi Undang-Undang Ketenagakaerjaan No. 13 Tahun 2003 Terhadap Iklim Investasi, Vol. 22 N0. 5, (Jakarta : Jurnal Hukum Bisnis, 2003), hal. 10.

${ }^{3}$ Ibid, hal 13.
}

apabila dibuat secara lisan maka dinyatakan sebagai perjanjian kerja waktu tidak tertentu;

3. Dalam Bahasa Indonesia dan huruf latin atau dalam Bahasa Indonesia dan bahasa asing dengan Bahasa Indonesia sebagai yang utama;

4. Tidak ada masa percobaan kerja (probation), bila disyaratkan maka perjanjian kerja Batal Demi Hukum (Pasal 58 UU No. 13/2003).

Perjanjian Kerja Waktu Tidak Tertentu (PKWTT), berdasarkan Pasal 1 angka 2 Keputusan Menteri Tenaga Kerja dan Transmigrasi Republik Indonesia Nomor KEP. 100/MEN/VI/2004 Tentang Ketentuan Pelaksanaan Perjanjian Kerja Waktu Tertentu, pengertian Perjanjian Kerja Waktu Tidak Tertentu adalah perjanjian kerja antara pekerja/buruh dengan pengusaha untuk mengadakan hubungan kerja yang bersifat tetap. Pekerjanya sering disebut karyawan tetap.

PKWTT dapat juga dibuat secara lisan dan tidak wajib mendapat pengesahan dari intstansi ketenagakerjaan terkait. Jika PKWTT dibuat secara lisan maka perusahaan wajib membuat surat pengangkatan kerja bagi pekerja/karyawan yang bersangkutan. PKWTT dapat mensyaratkan adanya masa percobaan kerja (probation) untuk paling lama 3 (tiga) bulan, bila ada yang mengatur lebih dari 3 bulan, maka demi hukum sejak bulan keempat, si pekerja sudah dinyatakan sebagai pekerja tetap (PKWTT). Selama masa percobaan, Perusahaan wajib membayar upah pekerja dan upah tersebut tidak boleh lebih rendah dari upah minimum yang berlaku.

Bahkan adanya interprestasi bahwa PKWT dapat diperjanjikan dengan tidak didasarkan pada jenis, sifat atau kegiatan yang bersifat sementara dan melahirkan praktek perjanjian anatara pekerja dengan pengusaha yang tidak sesuai dengan tujuan pengaturan PKWT. (Pasal 59 UU No. 13 Tahun 2003 Tentang Ketenagakerjaan).

Praktik-praktiknya yang menyimpang dari ketentuan undang-undang ini merupakan 


\section{Asuan, Perlindungan Hukum Terhadap Pekerja Berstatus Perjanjian Kerja Waktu Tertentu (PKWT) \\ Menurut Undang-Undang Nomor 13 Tahun 2003 Tentang Ketenagakerjaan, Halaman 23-31}

salah satu dari tuntutan pekerja pada saat melakukan demonstrasi besar-besar. Kondisi pekerja yang sudah memperhatikan ditambah adanya diskriminasi perlindungan terhadap pekerja PKWT. $^{4}$

Terlepas dari tujuan pengusaha untuk meningkatkan daya saing dan efisiensi, juga tujuan pengusaha agar dapat menciptakan kesempatan kerja seluas-luasnya, perlindungan hukum terhadap pekerja juga harus tetap menjadi prioriras. Perlindungan bagi pekerja biasanya berhadapan dengan kepentingan pengusaha untuk tetap bertahan dalam menjalankan usahanya. Sehingga seringkali pihak terkait secara langsung adalah pengusaha dan pekerja yang mengakibatkan perlindungan terhadap pekerja dengan PKWT menjadi sangat lemah. ${ }^{5}$

Menghadapi realita tersebut, peran pemerintah diperlukan untuk melakukan campur tangan dengan tujuan mewujudkan perburuhan yang adil melalui pengaturan perundang-undangan. Hubungan antara pengusaha dan pekerja idealnya merupakan hubungan yang saling menguntungkan, namun dalam kenyataannya posisi pekerja tidak seimbang dengan posisi pengusaha.

Ketidakseimbangan posisi tersebut di antaranya karena rendahnya pendidikan pekerja sehingga tidak mengetahui hak dan kewajibannya, tidak memiliki keahlian khusus serta regulasi dalam hukum perburuhan tidak seimbang dalam mengatur hak dan kewajiban pihak pekerja dan pengusaha.

Melihat kenyataan di atas, dituntut adanya perlindungan terhadap pekerja khususnya berstatus perjanjian kerja waktu tertentu (PKWT). Ditinjau dari segi perlindungan perburuhan, maka UndangUndang No. 13 tahun 2003 tentang Ketenagakerjaan diharapkan dapat

\footnotetext{
${ }^{4}$ Tim Kontan, Ada Apa Dengan Buruh, Majalah Kontan Vol. II/EDISI XXIII, 07-20 Mei 2006, hal. 9, Diakses melalui Internet tanggal 2 September 2017 tentang Perlindungan Pekerja.

${ }^{5}$ Eggy Sudjana, Nasip dan Perjuangan Buruh di Indonesia, Renaissan, Jakarta, 2005, hal. 1.
}

memberikan perlindungan pekerj yang dapat dilihat dari tiga aspek, yaitu aspek perlindungan sosial, perlindungan ekonomi dan perlindungan teknis.

Dari uraian diatas untuk mengetahui tentang hak dan kewajiban antara pekerja dan pihak pengusaha, perlindungan terhadap pekerja yang berstatus perjanjian kerja waktu tertentu (PKWT), dan menyusun karya ilmia dengan judul : "PERLINDUNGAN HUKUM TERHADAP PEKERJA BERSTATUS PERJANJIAN KERJA WAKTU TERTENTU (PKWT) MENURUT UNDANG-UNDANG NO 13 TAHUN 2003 TENTANG KETEANAGAKERJAAN".

\section{B. Permasalahan}

Dari uraian diatas permasalahan yang ingin dibahas, yaitu :

1. Bagaimana perlindungan hukum terhadap pekerja dalam perjanjian kerja waktu tertentu (PKWT) menurut UndangUndang No. 13 Tahun 2003 tentang Keteanagakerjaan?

2. Apa yang menjadi hambatan-hambatan dalam perlindungan hukum terhadap pekerja dalam perjanjian kerja waktu tertentu (PKWT) ?

\section{Tujuan dan Manfaat Penelitian}

Dari uraian diatas tujuan dalam penelitian ini, yaitu :

1. Untuk mengetahui perlindungan hukum terhadap pekerja dalam perjanjian kerja waktu tertentu (PKWT) menurut UndangUndang No. 13 Tahun 2003 tentang Keteanagakerjaan?

2. Apa yang menjadi hambatan-hambatan dalam perlindungan terhadap pekerja dalam perjanjian kerja waktu tertentu (PKWT) ?

Manfaat dalam penelitian ini untuk:

\section{Secara teoritis}

Penelitian ini diharapkan dapat memperluas wawasan, pengetahuan serta memberikan gambaran lebih jelas tentang bagaimana perlindungan hokum bagi pekerja dalam perjanjian kerja waktu 
Asuan, Perlindungan Hukum Terhadap Pekerja Berstatus Perjanjian Kerja Waktu Tertentu (PKWT)

Menurut Undang-Undang Nomor 13 Tahun 2003 Tentang Ketenagakerjaan, Halaman 23-31

tertentu. Penelitian ini diharapkan dapat berguna bagi peneliti dan bahan bacan di perpustakaan dan penletian sebagai bahan acuan untuk penelitian yang akan tentang ketenegakerjaan pada umumnya.

2. Secara praktis

Hasil penelitian ini diharapkan dapat memberikan sumbangan pemikiran dalam kegiatan usaha/perusahaan, serta masyarakat, pelaku usaha yang khususnya berkecimpung dalam dunia ketenagakerjaan. Terutama mengenai perlindungan hokum bagi pekerja dalam perjanjian kerja waktu tertentu sehingga apa yang menjadi aturan di perusahan tidak bertentangan dengan Undang-Undang Nomor 13 Tahun 2003 Tentang Ketenagakerjaan dan peraturan lainnya.

\section{Metode Penelitian}

Pendekatan dalam penelitian ini yuridis normatif. Pendekatan yuridis adalah pendekatan terhadap masalah dengan cara melihat dari segi peraturan perundangan yang berlaku khususnya tentang hukum ketenagakerjaan/perburuhan, yaitu Perlindungan Hukum Terhadap Pekerja Dalam Perjanjian Kerja Waktu Tertentu (PKWT) menurut Undang-Undang No.13 tahun 2003 tentang Ketenagakerjaan.

Normatif adalah pendekatan yang hanyalah menggunakan data sekunder dengan penyusunan kerangka secara konsepsionil. Penelitian normatif dilakukan untuk mendapatkan bahan-bahan hukum berupa teoriteori, konsep-konsep dan asas-asas hukum yang diperoleh dari kepustakaan antara lain buku, dokumen, artikel, serta literatur lainnya. Peraturan perundang-undangan yaitu UndangUndang No. 13 Tahun 2003 tentang Ketenagakerjaan, KUH Perdata dan peraturan hukum lainnya berhubungan dengan permasalahan

\section{PEMBAHASAN}

A. Perlindungan hukum pekerja dalam perjanjian kerja waktu tertentu (PKWT) Menurut UU No. 13 Tahun 2013 tentang Ketenagakerjaan
Perjanjian kerja waktu tertentu harus dibuat secara tegas dinyatakan jangka waktu berlakunya perjanjian. Menurut KEPMEN No. 100 Tahun 2004 perjanjian kerja waktu tertentu adalah perjanjian kerja pekerja/buruh dengan pengusaha untuk mengadakan hubungan kerja dalam waktu tertentu atau untuk pekerja tertentu.

Hubungan kerja antara perusahaan dengan tenaga kerja adalah terikat dengan suatu ikatan perjanjian, yaitu seseorang yang tidak boleh diperbudak, diperlulur maupun diperhambatkan, kesepakatan kerja waktu tertentu merupakan salah satu sarana dalam rangka pelaksanaan hubungan industrial yang serasi, aman dinamis berdasarkan pancasila. Tata cara pembuatan kesepakatan kerja waktu tertentu yang ada perlu dilengkapi dengan berpedoman kepada isi dan jiwa hubungan industrial pancasila. Tujuan dibuatnya perjanjian kerja waktu tertentu adalah untuk mempertegaskan dan memperjelas hak dan kewajiban, menetapkan secara bersama mengenai syarat-syarat kerja berdasarkan Undang-Undang No. 13 Tahun 2003 tentang Ketenagakerjaan dan peraturan perusahaan sehingga dapat mendorong terciptanya hubungan industrial yang harmonis, dinamis dan keadilan, turut serta melindungi pihak yang lemah (pekerja) dari kekuasaan pengusaha, guna menetapkannya pada kedudukan yang layak sesuai dengan harkat dan martabat manusia.

Menyadari akan pentingnya pekerja bagi perusahaan, dalam dunia outsourcing, baik dalam pemborongan pekerjaan maupun penyediaan jasa tenaga kerja, perusahaan diwajibkan menjamin perlindungan/jaminan terhadap hak-hak pekerja/ buruh. perlindungan tersebut dimulai dengan adanya kewajiban, bahwa perusahaan harus berbadan hukum. Bila kita berbicara masalah perlindungan kerja dan syarat-syarat kerja, maka hal ini merupakan masalah yang sangat komplek karena akan berkaitan dengan kesehatan kerja, keselamatan kerja, upah, kesejahteraan, dan jamsostek. Undang-Undang No. 13 tahun 2003 telah mengatur semua di dalam pasal- pasalnya. Menurut Soepomo, perlindungan tenaga kerja dibagi menjadi 3 (tiga) macam, 
Asuan, Perlindungan Hukum Terhadap Pekerja Berstatus Perjanjian Kerja Waktu Tertentu (PKWT) Menurut Undang-Undang Nomor 13 Tahun 2003 Tentang Ketenagakerjaan, Halaman 23-31

yaitu :

a. Perlindungan ekonomis, yaitu perlindungan tenaga kerja dalam bentuk penghasilan yang cukup, termasuk bila tenaga kerja tidak mampu bekerja di luar kehendaknya.

b. Perlindungan sosial, yaitu : perlindungan tenaga kerja dalam bentuk jaminan kesehatan kerja, dan kebebasan berserikat dan perlindungan hak untuk berorganisasi.

c. Perlindungan teknis, yaitu : perlindungan tenaga kerja dalam bentuk keamanan dan keselamatan kerja. ${ }^{6}$

Menurut Undang-Undang No. 13 Tahun 2003 tentang Ketenagakerjaan mengatur perlindungan hukum terhdapa pekerja dengan perjanjian kerja antar waktu (PKWT) sebagai berikut :

\section{a. Perlindungan terhadap waktu kerja}

Pemberian waktu kerja tersebut telah sesuai dengan Undang-Undang Nomor 13 Tahun 2003 Tentang Ketenagakerjaan Pasal 77 sebagai berikut :

(1). Setiap pengusaha wajib melaksanakan ketentuan waktu kerja

(2). Waktu kerja sebagaimana dimaksud dalam ayat (1) meliputi :

a. 7 (tujuh) jam dalam 1 (satu) hari dan 40 jam 1 (satu) minggu untuk 6 (enam) hari kerja dalam 1 (satu) minggu; atau

b. 8 (delapan) jam dalam 1 (satu) hari dan 40 jam 1 (satu) minggu untuk 5 (lima) hari kerja dalam 1 (satu) minggu.

b. Perlindungan terhadap pengupahan

Dampak langsung yang dialamiu pekerja atas statusbsebagai pekerja kontrak adalah soal upah, ada kecenderungan menurunkan besaran upah saat pekerja menjadi pekerja kontrak yang

${ }^{6}$ Imam Soepomo, Hukum Perburuhan dalam bidang hubungan kerja, Djambatan, Jakarta, 1987, hal. 51. disebut perjanjian kerja untuk waktu tertentu (PKWT). Hal ini mengakibatkan diskriminasi upah antara pekerja tetap dan pekerja kontrak/ perjanjian kerja untuk waktu tertentu walaupun jenis pekerjaan yang dilakukan sama.

Upah adalah hak pekerja/buruh yang diterima dan dinyatakan dalam bentuk uang sebagai imbalan dari pengusaha atau pemberi kerja kepada pekerja/buruh yang ditetapkan dan dibayarkan menurut suatu perjanjian kerja, kesepakatan, atau peraturan perundangundangan, termasuk tunjangan bagi pekerja/buruh dan keluarganya atas suatu pekerjaan dan/atau jasa yang telah atau akan dilakukan, (Pasal 1 angka 30 Undang-Undang Nomor 13 Tahun 2003).

Suatu penerimaan sebagai imbalan dari pengusaha kepada buruh/pekerja untuk sesuatu pekerjaan atau jasa yang telah dilakukan atau akan dilakukan, dinyatakan atau dinilai dalam bentuk uang yang ditetapkan menurut suatu persetujuan atau perundang-undangan dan dibayarkan atas dasar suatu perjanjian kerja antara pengusaha dengan buruh, termasuk tunjangan, baik buruh/pekerja sendiri maupun keluarganya, (Pasal 1 huruf a Peraturan Pemerintah No. 8 Tahun 1981). ${ }^{8}$

Dari penjelasan dua (2) peraturan perundang-undangan di atas, maka upah diberikan dalam bentuk uang, namun secara normatif masih ada kelonggaran bahwa upah dapat diberikan dalam bentuk lain berdasarkan perjanjian atau peraturan perundanganundangan, dengan batasan nilainya tidak boleh dari 25\% (dua puluh lima persen) dari upah yang seharusnya diterima (Pasal 12 Peraturan Pemerintah No. 8 Tahun 1981).

Menurut pasal 1 ayat (1) Peraturan Menteri Tenaga Kerja Nomor PER01/MEN/1999 Tentang Upah Minimum, yaitu upah bulanan terendah yang terdiri dari upah pokok termasuk tunjangan tetap. Berdasarkan Peraturan Menteri Tenega Kerja Nomor PER-

\footnotetext{
${ }^{7}$ Husni, Lalu, Pengantar Hukum Ketenagakerjaan Indonesi,. Raja Grafindo Persada, Jakarta. 2003, hal. 53

${ }^{8}$ J.S, Payaman, Hukum Ketenagakerjaan Indonesia (edisi revisi), PT. Raja Grafindo, Jakarta. 2004, hal.42
} 
Asuan, Perlindungan Hukum Terhadap Pekerja Berstatus Perjanjian Kerja Waktu Tertentu (PKWT)

Menurut Undang-Undang Nomor 13 Tahun 2003 Tentang Ketenagakerjaan, Halaman 23-31

01/MEN/1999 jo. Keputusan Menteri Tenaga

c. Perlindungan terhadap kesejahteraan

Kerja dan Transmigrasi Nomor KEP226/ME/2000, jangkauan wilayah berlakunya upah minimun meliputi :

1. Upah Minumun Provinsi (UMP) berlaku di seluruh Kabupaten/Kota dalam 1 (satu) wilayah provinsi;

2. Upah Minimum Kabupaten/Kota (UMK) berlaku dalam 1 (satu) wilayah Kabupaten/Kota.

Di Samping itu, upah minimum berdasarkan Kelompok Lapangan Usaha Indonesia (KLUI) dapat disebut Upah Minimum Sektoral, yang terbagi menjadi upah Upah Minimum Sektoral Provinsi (UMSP) dan Upah Minimum Sektoral Kabupaten/Kota (UMSK).

Berdasarkan Pasal 6 Peraturan Menteri Tenega Kerja Nomor PER01/MEN/1999, penetapan upah minimum dilakukan dengan mempertimbangkan :

a. Kebutuhan Hidup Minimum (KHM )

b. Indeks Harga Konsumen (IHK)

c. Kemampuan, perkembangan dan kelangsungan perusahaan

d. Upah pada umumnya berlaku di daerah tertentu dan antar daerah

e. Kondisi pasar kerja

f. Tingkat perkembangan perekonomian dan pendapatan perkapita

Sebagaimana Pasal 89 ayat (1) Undang-Undang Nomor 13 Tahun 2003 tentang Ketenagakerjaan yang berbunyi : upah minimum sebagimana dimaksud dalam Pasal 88 ayat (3) huruf a Undang-Undang Nomor 13 Tahun 2003 tentang Ketenagakerjaan dapat terdiri dari :

1. Upah minimum berdasarkan wilayah provinsi atau kabupaten/ kota;

2. Upah minimum berdasarkan sektor pada wilayah provinsi atau kabupaten/kota;

Menyadari akan pentingnya pekerja bagi perusahaan, perusahaan wajib untuk untuk menjamin kesejahteraan dari tenaga outsourcing, Perjanjian Kerja Waktu Tertentu (PKWT).elah mengatur sebagai berikut :

1. Setiap pekerja/buruh dan keluarganya berhak untuk memperoleh jaminan sosial tenaga kerja. (Pasal 99 ayat (1)).

2. Untuk meningkatkan kesejahteraan bagi pekerja/buruh dan keluarganya, pengusaha wajib menyediakan fasilitas kesejahteraan yang meliputi pelayanan keluarga berencana, tempat penitipan anak, perumahan pekerja/buruh, fasilitas beribadah, fasilitas olahraga, fasilitas kantin, fasilitas kesehatan dan fasilitas rekreasi tentunya penyediaan fasilitas tersebut dilaksanakan dengan memperhatikan kebutuhan pekerja/buruh dan ukuran kemampuan perusahaan. (Pasal 100 ayat (1) dan ayat (2))

3. Untuk meningkatkan kesejahteraan pekerja/buruh dibentuk koperasi pekerja/buruh dan usaha-usaha produktif di perusahaan yaitu kegiatan yang bersifat ekonomis yang menghasilkan pendapatan diluar upah. (Pasal 101 ayat (1))

d. Perlindungn terhadap jamsostek

Program Jaminan Sosial

Tenaga Kerja (Program Jamsostek) merupakan bentuk perlindungan ekonomis dan perlindungan sosial. Dikatakan demikian karena program ini memberikan perlindungan dalam bentuk santunan berupa uang atas berkurangnya penghasilan dan perlindungan dalam bentuk pelayanan dan perawatan/pengobatan pada saat 
Asuan, Perlindungan Hukum Terhadap Pekerja Berstatus Perjanjian Kerja Waktu Tertentu (PKWT)

Menurut Undang-Undang Nomor 13 Tahun 2003 Tentang Ketenagakerjaan, Halaman 23-31

seorang pekerja tertimpa risiko-risiko tertentu.

Program Jamsostek merupakan kelanjutan dari program Asuransi Sosial Tenaga Kerja (ASTEK) yang didirikan menurut Peraturan Pemerintah Nomor 33 Tahun 1977. Secara yuridis penyelenggaraan program Jamsostek dimaksudkan sebagai pelaksanaan Pasal 10 dan Pasal 15 Undang-Undang Nomor 14 Tahun 1969 tentang Ketentuanketentuan Pokok mengenai Tenaga Kerja (yang sekarang sudah dicabut dan diganti dengan Undang-Undang Nomor 13 Tahun 2003 tentang Ketenagakerjaan, yang diatur dalam Pasal 99 yang pelaksanaannya sementara ini masih mengikuti ketentuan dalam Undang-Undang Nomor 3 Tahun 1992 tentang Jaminan Sosial Tenaga Kerja (JAMSOSTEK) berikut aturan pelaksanaannya yaitu PP No. 14 tahun 1993, PP No, 64 tahun 2005 tentang perubahan ke empat atas PP No, 14 Tahun 1993 tentang Penyelenggaraan Jamsostek. Program Jamsostek meliputi jaminan Kematian, Jaminan Kecelakaan Kerja, Jaminan Hari Tua dan Jaminan Pemeliharaan Kesehatan. Penyelenggaraan Program Jamsostek diwajibkan bagi pengusaha yang memiliki tenaga kerja minimal 10 (sepuluh) orang. ${ }^{9}$

\section{B. Hambatan-hambatan dalam perlindungan hukum terhadap pekerja dalam perjanjian kerja waktu tertentu (PKWT)}

Dalam pelaksanaan pemberian perlindungan terhadap para pekerja dengan sistem Perjanjian Kerja Waktu Tertentu (PKWT) tidak selalu bisa berjalan dengan baik sesuai dengan

\footnotetext{
${ }^{9}$ Rusli, Hardijan. Hukum Ketenagakerjaan, Ghalia Indonesia., Jakarta, 2003, hal. 32
}

yang diharapkan dan diinginkan untuk terjadi oleh para pembuat undangundang. Pada pelaksanaannya terdapat berbagai kendala yang menghambat tercapainya keinginan dari pembuat undang-undang. Hal yang sama juga terjadi terhadap pemberian perlindungan bagi para pekerja/buruh yang bekerja dengan sistem Perjanjian Kerja Waktu Tertentu (PKWT). Di mana banyak kalangan yang kemudian menjadi resah terhadap keadaan yang terjadi dan berkembang. ${ }^{10}$

Kendala-kendala yang terdapat dalam pemberian perlindungan terhadap pekerja/buruh yang bekerja dengan sistem Perjanjian Kerja Waktu Tertentu (PKWT) antara lain adalah :

a. Kendala yang berkaitan dengan Peraturan

b. Kendala yang berkaitan dengan Perjanjian Kerja

c. Kendala yang berkaitan dengan Pengawasan

Berdasarkan semua keterangan di atas, maka kendala-kendala yang dihadapi dalam pelaksanaan perjanjian kerja waktu tertentu (PKWT) terhadap pemberian perlindungan pekerja/buruh adalah kendala yang berkaitan dengan peraturan yang ada terutama yang berkaitan dengan pelaksanaan perjanjian kerja waktu tertentu (PKWT), selain itu juga ada kendala yang berkaitan dengan perjanjian kerja dimana dalam perjanjian kerja sering dibuat berat sebelah (sepihak) yang banyak merugikan pekerja/buruh, apalagi pekerja/buruh perjanjian kerja waktu tertentu (PKWT). Terakhir adalah kendala pengawasan yang terjadi sebagai dampak dari lemahnya aturan hukum yang ada, salah satunya tentang kontrak kerja dimana dalam kontrak kerja tidak dijelaskan secara rinci pekerjaan apa yang dilakukan, sehingga menyulitkan

${ }^{10}$ Ibid, hal 49 
untuk melakukan pengawasan di lapangan. Solusinya, untuk kendala yang bekaitan dengan peraturan yang kurang jelas, pemerintah sebaiknya segera melakukan perbaikan terhadap pengaturan pada pekerja/buruh Perjanjian Kerja Waktu Tertentu (PKWT), agar para pekerja/buruh Perjanjian Kerja Waktu Tertentu (PKWT) mendapatkan perlindungan hukum yang lebih baik. ${ }^{11}$

Salah satu bukti kelemahan hukum yang mengatur tentang Perjanjian Kerja Waktu Tertentu (PKWT) adalah, adanya kasus yang terjadi pada pekerja/buruh Perjanjian Kerja Waktu Tertentu (PKWT) yang ada di tiap perusahaan.

Untuk kendala yang bekaitan dengan perjanjian kerja, menurut penulis, kalau perlu demi meningkatkan perlindungan terhadap para pekerja/buruh, pemerintah membuat format perjanjian kerja yang secara baku untuk Perjanjian Kerja Waktu Tertentu (PKWT), karena hal ini akan lebih memudahkan bagi pemerintah dalam melakukan pengawasan. Untuk kendala yang berkaitan dengan pengawasan, sebaiknya setiap pegawai pengawas diberikan kewenangan untuk melakukan penindakan langsung terhadap pelanggaran yang terjadi pada pekerja/buruh Perjanjian Kerja Waktu Tertentu (PKWT) yang dilakukan oleh perusahaan, sehingga fungsi pengawasan dapat memberikan efek jera terhadap para pengusaha yang melakukan pelanggaran atau bermainmain dengan aturan hukum yang menyebabkan berkurangnya perlindungan yang didapatkan oleh pekerja/buruh Perjanjian Kerja Waktu Tertentu (PKWT).

\section{PENUTUP}

1. Perlindungan pekerja dengan perjanjian kerja antar waktu (PKWT) sebagai berikut:

a. Perlindungan terhadap pengupahan yaitu upah minimum propinsi dan upah minimum kabupaten/kota (Pasal 88 ayat (3) huruf a Undang-Undang Nomor 13 Tahun 2003 tentang Ketenagakerjaan).

b. Perlindungan terhadap waktu kerja yaitu 7 (tujuh) jam dalam 1 (satu) hari dan 40 jam 1 (satu) minggu untuk 6 (enam) hari kerja dalam 1 (satu) minggu; atau 8 (delapan) jam dalam 1 (satu) hari dan 40 jam 1 (satu) minggu untuk 5 (lima) hari kerja dalam 1 (satu) minggu. (Pasal 77 ayat Undang-Undang Nomor 13 Tahun 2003 tentang Ketenagakerjaan)

c. Perlindungan terhadap kesejahteraan yaitu Setiap pekerja/buruh dan keluarganya berhak untuk memperoleh jaminan sosial tenaga kerja. (Pasal 99 ayat (1)), meliputi pelayanan keluarga berencana, tempat penitipan anak, perumahan pekerja/buruh, fasilitas beribadah, fasilitas olahraga, kantin, kesehatan, rekreasi dan dibentuknya fasiltas koperasi tentunya penyediaan fasilitas tersebut dilaksanakan dengan kemampuan perusahaan (Pasal 100 ayat 1 dan 2 ) Undang-Undang Nomor 13 Tahun 2003 tentang Ketenagakerjaan)

d. Perlindungan terhadap jamsostek yaitu Program Jamsostek meliputi jaminan Kematian, Jaminan Kecelakaan Kerja, Jaminan Hari Tua dan Jaminan Pemeliharaan Kesehatan (pasal 99 Undang-Undang Nomor 13 Tahun 2003 tentang Ketenagakerjaan

2. Hambatan-hambatan dalam perlindungan hukum terhadap pekerja dalam perjanjian kerja waktu tertentu (PKWT) yaitu berkaitan dengan peraturan, berkaitan dengan perjanjian kerja dan berkaitan dengan pengawasan

\footnotetext{
${ }^{11}$ Op. Cit, hal 51.
} 
Aloysius Uwiyono, Implikasi Undang-Undang Ketenagakaerjaan No. 13 Tahun 2003 Terhadap Iklim Investasi, Vol. 22 N0. 5, (Jakarta : Jurnal Hukum Bisnis, 2003

Eggy Sudjana, Nasip dan Perjuangan Buruh di Indonesia, Renaissan, Jakarta, 2005

Husni, Lalu, Pengantar Hukum Ketenagakerjaan Indonesi,. Raja Grafindo Persada, Jakarta. 2003

Imam Soepomo, Hukum Perburuhan dalam bidang hubungan kerja, Djambatan, Jakarta, 1987

------------,Pengantar Hukum Perburuhan, Penerbit Djambatan, Jakarta, 1987 Jakarta, 1987

J.S, Payaman, Hukum Ketenagakerjaan Indonesia (edisi revisi), PT. Raja Grafindo, Jakarta. 2004

Rusli, Hardijan. Hukum Ketenagakerjaan, Ghalia Indonesia., Jakarta, 2003

Tim Kontan, Ada Apa Dengan Buruh, Majalah Kontan Vol. II/EDISI XXIII, 07-20 Mei 2006, hal. 9, Diakses melalui Internet tanggal 2 September 2017

Undang-Undang : tentang Perlindungan Pekerja.

1. Undang-Undang No 13 tahun 2003 Tentang Ketenakerjaan

2. PP No, 14 Tahun 1993 tentang Penyelenggaraan Jamsostek.

3. Kepmenaker No. KEP.100/MEN/VI/2004 Tentang Ketentuan Pelaksanaan Perjanjian Kerja Waktu Tertentu 